\title{
STRESS MASYARAKAT DI MASA PANDEMI
}

\author{
Ade Herawati Sahputri
}

\author{
adehera92@gmail.com
}

\section{Latar Belakang}

Kesehatan mental adalah keadaan sejahtera di mana setiap individu bisa mewujudkan potensi mereka sendiri secara maksimal. Kesehatan mental tidak dapat dipisahkan dari kesehatan fisik yang baik. Kesehatan fisik yang baik sama pentingnya bagi manusia seperti kesehatan fisik setiap orang. Kesehatan mental dapat dipengaruhi oleh kejadian atau peristiwa dalam hidup yang dapat sangat mempengaruhi karakter dan perilaku seseorang. Jika kesehatan mental terganggu, maka timbul gangguan mental atau penyakit mental. Gangguan kesehatan mental dapat mengubah cara seseorang dalam bersikap, menangani stres, berhubungan dengan orang lain, membuat pilihan, dan memicu hasrat untuk menyakiti diri sendiri.

Coronavirus disease tahun 2019 atau Covid19 adalah jenis baru dari Coronavirus, selain memberikan dampak fisik dapat juga memiliki efek serius pada kesehatan mental seseorang. Berbagai gangguan psikologis telah dilaporkan dan dipublikasi selama wabah Covid-19 di baik pada tingkat individu, komunitas, nasional, dan internasional. Pandemi bahkan menyebabkan krisis psikologis. Identifikasi individu pada tahap awal gangguan psikologis membuat strategi intervensi lebih efektif. Krisis kesehatan pandemi Covid-19 menyebabkan perubahan psikologis seperti ketakutan, kecemasan, depresi, atau ketidakamanan. Gangguan ini tidak hanya dirasakan oleh tenaga kesehatan atau semua orang yang bekerja di bidang medis, tetapi juga seluruh warga negara.

Penelitian terbaru melaporkan bahwa orang dengan pengalaman isolasi dan karantina memiliki perubahan signifikan pada tingkat kecemasan, kemarahan, kebingungan, dan stres. Masyarakat diluar tempat karantina mengalami ketakutan tertular karena pengetahuan tentang Covid-19 yang terbatas atau salah. Penelitian sebelumnya telah melaporkan bahwa kondisi wabah infeksi, seperti sindrom pernafasan akut yang parah (SARS) yang mirip dengan pandemi Covid-19, telah memberikan beban psikologis kepada para petugas kesehatan seperti kecemasan, depresi, serangan panik, atau gejala psikotik. Penelitian sebelumnya telah menyatakan bahwa gangguan mental dari suatu bencana besar memiliki dampak yang lebih luas dan lebih lama dibandingkan dengan cedera fisik, sedangkan perhatian pada kesehatan 
mental jauh lebih sedikit, baik dari segi pengadaan personel untuk perencanaan dan sumber daya.

Faktor penyebab stres diperlukan untuk memberikan pemahaman dan masukan untuk kebijakan yang strategis guna peningkatan kewaspadaan dan manajemen diri agar terhindar dari gangguan psikologis berupa stres di masa pandemi Covid-19.

\section{Metode}

Metode yang digunakan dalam kajian ini adalah metode literature review yaitu metode dengan cara membaca dari berbagai sumber seperti jurnal online serta membandingkan isi dari berbagai sumber yang dibaca dan menyimpulkan dalam hasil kajian yang didapatkan pada jurnal mengenai stress yang dialami oleh masyarakat dimasa pandemi, penyebab stress, bagaimana cara untuk melakukan manajemen stress dengan baik di masa pandemi.

\section{Hasil}

Dunia sedang mengalami masa yang berat sejak awal tahun 2020 ini karena dikejutkan dengan adanya fenomena Corona Virus Disease atau COVID-19. Berbagai negara termasuk Indonesia masih berjuang untuk mengatasi virus ini, karena dampaknya bukan hanya terjadi pada sektor kesehatan tetapi juga berbagai sektor lainnya (multidimensional) seperti perekonomian, pendidikan, juga interaksi sosial yang terjadi di masyarakat. Portal berita Tirto.id mencatat bahwa pada tanggal 5 Juni 2020, total kasus positif Corona di Indonesia mencapai 29.521 pasien, sedangkan tertinggi di dunia yaitu Amerika Serikat mencapai 1.872.660 dan diperkirakan akan terus meningkat setiap harinya .

Dalam merespon fenomena ini, Indonesia mengeluarkan beberapa kebijakan terutama dalam mengatur interaksi sosial masyarakatnya untuk mencegah angka penyebaran virus semakin tinggi. Mulai dari anjuran melakukan Social Distancing atau Physical Distancing hingga kebijakan resmi seperti Pembatasan Sosial Berskala Besar (PSBB) yang ditetapkan oleh pemerintah daerah. Kebijakan dan anjuran yang dilakukan pemerintah ini memberikan dampak yang cukup besar bagi kehidupan sosial masyarakat di Indonesia.

Penelitian terbaru melaporkan bahwa orang dengan pengalaman isolasi dan karantina memiliki perubahan signifikan pada tingkat kecemasan, kemarahan, kebingungan, dan stres. Masyarakat diluar tempat karantina mengalami ketakutan tertular karena pengetahuan tentang Covid-19 yang terbatas atau salah. Penelitian sebelumnya telah melaporkan bahwa kondisi wabah infeksi, seperti sindrom pernafasan akut yang parah (SARS) yang mirip dengan pandemi 
Covid-19, telah memberikan beban psikologis kepada para petugas kesehatan seperti kecemasan, depresi, serangan panik, atau gejala psikotik. Penelitian sebelumnya telah menyatakan bahwa gangguan mental dari suatu bencana besar memiliki dampak yang lebih luas dan lebih lama dibandingkan dengan cedera fisik, sedangkan perhatian pada kesehatan mental jauh lebih sedikit, baik dari segi pengadaan personel untuk perencanaan dan sumber daya

Penting untuk menyadari pengelolaan stres di tingkat masyarakat. Mengingat bahwa bagian dari populasi dengan status sosial ekonomi yang lebih rendah cenderung lebih rentan untuk hasil negatif terkait stres, mereka mungkin mendapat manfaat ketahanan khusus jangka pendek dan jangka panjang yang meningkatkan intervensi di tingkat masyarakat termasuk menjamin akses ke pendidikan dan informasi online, menyediakan akses yang memadai ke infrastruktur ekonomi dan kesehatan, merangsang masyarakat untuk mengatur diri mereka sendiri, dan mengambil inisiatif secara lokal.ss

\section{Pembahasan}

Stres merupakan reaksi yang berbahaya yang dimiliki oleh individu terhadap tekanan dan tuntutan yang tidak semestinya dibebankan kepada mereka Stres juga dapat menyebabkan individu berada dalam keadaan emosi dan dalam ketegangan sehingga individu tersebut tidak dapat berpikir dengan baik dan efektif, karena kemampuan rasional dan penalaran tidak berfungsi dengan baik. Stres memiliki efek langsung pada kesehatan masyarakat dan kinerja mereka, karena hal tersebut dapat dikatakan bahwa stres memiliki peranan yang cukup penting pada masalah organisasi.

Teori mengenai stress terus berkembang setiap jamannya, namun secara fundamental, teori stress dibangun dalam 3 pendekatan (Bartlett, 1998; Lyon, 2012; Lumban Gaol, 2016).:

1. Stres model stimulus (rangsangan), dengan kata lain stress ini merujuk pada hal-hal yang diterima langsung oleh individu tanpa adanya penilaian (Staal, 2004) Bartlett (1998) menegaskan bahwa stres ini lebih fokus pada sumber stres dari pada sumber lainnya. Sumber stress (stressor) dikategorikan berdasarkan tiga jenis yaitu (1) life events (peristiwa kehidupan) adalah perubahan besar yang memerlukan perilaku adaptasi dalam periode waktu yang relative singkat (misalnya kelahiran anak pertama, perceraian), (2) chronic strain (ketegangan kronis) merupakan tuntutan yang berulang juga membutuhkan penyesuaian kembali dalam waktu lama (misalnya melumpuhkan cidera, kemiskinan, masalah perkawinan), dan (3) daily hassles (permasalahan- 
permasalahan sehari-hari) yang merujuk kepada peristiwa kecil yang memerlukan penyesuaian perilaku kecil selama waktu yang singkat (misalnya kemacetan lalu lintas, pengunjung tak terduga, makan enak) (Thoits, 1995).

2. Stres model response (respon), Selye (1950) mendefisinikan stress ini sebagai hasil inividu merespon stimulus yang diberikan atau reaksi tanggapan tubuh terhadap penyebab stress yang mempengaruhi seseorang. Contoh stres ini apabila seseorang merasakan keadaan yang mengkhawatirkan, ancaman yang muncul kemudian direspon spontan oleh tubuh. Ancaman merupakan sumber stres, respon tubuh merupakan stres respon (Scheneidrman, Ironson \& Siegel, 2005; Lumban Gaol, 2016).

3. Stres model transactional (transaksional) yaitu sebagai penilaian dari individu terhadap suatu penyebab stres yang kemudian akan menentukan respon individu tersebut (Lumban Gaol, 2016; Staal, 2004). Berdasarkan adanya tuntutan-tuntutan yang timbul terhadap kondisi kesehatan, individu secara khusus menilai atau mengevaluasinya (Lyon, 2012).

Virus corona pertama kali muncul pada Desember 2019. Virus ini menyebabkan gangguan pernafasan dan sudah menyebar ke lebih dari 121 negara di dunia sehingga Organisasi Kesehatan Dunia (WHO) mendeklarasikan virus corona jenis baru penyebab COVID-19 sebagai pandemi global. Di Indonesia virus corona pertama kali ditemukan 2 Maret 2020 setelah 2 orang dinyatakan positif COVID-19. Sebagai upaya menghentikan laju penyebaran virus sebagian besar pemerintah di dunia menerapkan pembatasan kontak sosial mulai dari jaga jarak sosial, isolasi diri di rumah, pembatasan interaksi diluar rumah. Kebijakan serupa dilakukan di Indonesia yang dikenal dengan istilah PSBB (Pembatasan Sosial Berskala Besar) dengan kerja dari rumah, belajar dari rumah, dan ibadah di rumah, jaga jarak, memakai masker, mencuci tangan, dan dilarang berkerumun dalam jumlah yang banyak. Masyarakat diminta berdiam di rumah dan mengurangi kegiatan di luar rumah, membatasi pertemuan dan hanya tinggal di rumah dalam waktu lama tentu berpengaruh pada kesehatan mental.

Dampak psikologis juga disebabkan oleh kondisi pandemi. Dimana pandemi mampu menimbulkan dampak yang cukup luas dan mempengaruhi stabilitas ekonomi, sosial, politik, hingga psikologis. Saat pandemi terjadi, aspek emosional manusia adalah yang paling pertama diserang Peningkatan masalah kesehatan mental seperti kecemasan, depresi, gejala seperti stres pasca trauma, insomnia, dan kemarahan di antara populasi umum, tenaga kesehatan, serta orang yang diisolasi karena terinfeksi corona virus atau kontak dengan orang yang terinfeksi . 
Dampak psikologis dapat berupa ketakutan, kecemasan, stres, ketidakpastian, maupun perilaku konsumen yang berlebihan seperti panic buying. Stress dapat memicu gangguan sosial seperti kepanikan dan penimbunan alat medis. Stress pada masa pandemic COVID-19 muncul akibat masyarakat cenderung menganggap corona virus merupakan virus baru yang mengancam dan memiliki resiko lebih tinggi dibandingkan dengan ancaman yang lebih umum seperti influenza. Respon stres meningkat saat ada kejadian yang mengancam kesehatan fisik dan mental. Selain itu respon stres dapat meningkatkan suatu perilaku mencari bantuan yang tidak seimbang dan tidak tepat untuk dilakukan dalam menanggapi sebuah ancaman aktual. Pada masa pandemi COVID-19, terlihat perilaku masyarakat yang menunjukkan kondisi stres contoh: berperilaku berlebihan dengan menggunakan pakaian hazmat saat belanja kebutuhan sehari-hari, membeli barang-barang tertentu secara berlebihan (seperti: hand sanitizer dan masker). Kecemasan yang terjadi pada masyarakat luas dapat mengakibatkan terjadinya panic buying saat wabah COVID19 . Stress juga dapat disebabkan karena masih simpang siurnya informasi dikarenakan COVID-19 adalah penyakit baru, kemunculan dan penyebarannya, menyebabkan kebingungan, kecemasan dan ketakutan di kalangan masyarakat umum. Banyak fakta terus berubah dan banyak mitos juga tersebar mengenai cara pencegahan dan pengelolaan infeksi.

Faktor lain yang menyebabkan masyarakat di berbagai negara mengalami gangguan psikologis adalah: (1) Pesta minuman keras yang menjadi pelarian dari rasa cemas dan kebosanan secara signifikan dan positif meningkatkan depresi, kecemasan dan stres. Organisasi Kesehatan Dunia (WHO) melaporkan konsumsi alkohol dapat meningkatkan risiko dari infeksi Covid-19. (2)Status bekerja secara signifikan terkait dengan depresi dan kecemasan spekulasi tentang pemotongan gaji dan ketidakpastian atau ketidakamanan masa depan mungkin terjadi. Selain itu karena larangan perjalanan, kantor ditutup dan beberapa karyawan bekerja dari rumah. Beberapa karyawan tidak terbiasa dan tidak bisa untuk memenuhi tenggat waktu atau target dan tekanan kerja. (3) Jenis kelamin dimana beberapa penelitian melaporkan laki-laki lebih cenderung cemas. Survei Mental Nasional India tahun 2016 yang melaporkan bahwa perempuan lebih mungkin cemas daripada laki-laki (Verma and Mishra, 2020).

Salah satu metode yang dapat dilakukan oleh seorang pekerja sosial dalam melakukan praktik konseling terhadap klien individu, keluarga, kelompok yaitu dengan melakukan relaksasi. Relaksasi adalah suatu kegiatan melemaskan otot-otot pada tubuh yang berguna untuk mengurangi ketegangan yang dirasakan oleh tubuh (Sari \& Murtini). 
Manfaat yang dapat dirasakan setelah melakukan proses relaksasi antara lain menurut (Utami, 2001) yaitu:

1. Membantu seseorang lebih mampu menghindari melakukan hal-hal yang berlebihan akibat dari stress.

2. Berkurangnya masalah yang timbul akibat stres seperti akit kepala, tekanan darah tinggi, insomnia dan perilaku buruk lainnya.

3. Mengurangi kecemasan dan menunjukan efek psikologis yang positif pada seseorang.

4. Meningkatkan semangat dalam menjalankan aktivitas.

\section{Meningkatkan hubungan interpersonal}

Proses kegiatan relaksasi ini berpegang kuat pada pengaturan pernapasan serta sugesti agar dapat merasakan ketenangan dan menghilangkan kecemasan. Agar klien merasakan rileks di seluruh tubuhnya dari ujung kepala hingga ujung kaki, aktivitas relaksasi ini dilakukan dengan memberikan sugesti kepada klien. Selain itu, klien juga dituntun untuk dapat mengistirahatkan pikirannya dan merasakan kenyamanan, damai, bahagia atau perasaan positif lainnya pada dirinya (Budi, 2010). Maka selanjutnya tantangan dalam keberhasilan dari kegiatan relasasi untuk menghilangkan kecemasan bahkan stres semasa pandemi ini adalah penyampaian sugesti yang kuat agar dapat diterima dengan baik oleh klien atau siapapun yang melaksanakan kegiatan tersebut.

Kegiatan relaksasi awalya merupakan kegiatan yang dipandu dan dilakukan secara langsung kepada seorang klien tetapi semakin berkembangnya zaman, paa masa dan era digital ini sudah banyak platform atau media yang memudahkan orang mengakses dan melakukan relaksasi secara individu maupun kelompok dalam satu lokasi yang sama. Bahkan, Ikatan Psikolog Klinis Indonesia menyediakan Audio Panduan Relaksasi Meredakan Stres Pikiran dan Tubuh dalam rangka dukungan psikologis kepada masyarakat Indonesia untuk mengatasi kecemasan dalam menghadapi masa pandemic Covid-19 (Ikatan Psikolog Klinis Indonesia, 2020). Selain itu, konsep relaksasi dalam platform digital ini sudah banyak hadir salah satunya dalam kanal Youtube dengan menggunakan audiovisual yang memandu penonton dalam melakukan relaksasi lengkap dengan ilustrasi, sugesti juga membantu secara pendengaran yang seakanakan berada dalam situasi yang nyaman. Selain itu salah satu media music player yang popular di masyarakat di Indonesia yaitu bahkan menambahkan kategori relaxation (relaksasi) apabila pendengarnya menjelajahi halaman Wellness. Kategori ini merujuk pada playlist yang 
kemudian menyuguhkan pendengarnya dengan berbagai podcast maupun audio yang membuat keadaan diri bisa lebih relaks.

Saat ini, belum ada perkiraan akurat tentang berapa lama situasi COVID-19 akan bertahan, jumlah orang di seluruh dunia yang akan terinfeksi, atau berapa lama hidup orang akan terganggu (Suicide Awareness Voices of Education, 2020; Zandifar \& Badrfam, 2020). Karena kehidupan harus tetap berjalan, maka langkah awal yang dilakukan adalah penerimaan (acceptance). Penerimaan berarti memberi ruang kesadaran yang penuh kepada diri bahwa pandemi COVID-19 adalah sebuah kenyataan. Jika kita sudah menerima bahwa kondisi sekarang bukanlah kondisi normal, maka kita siap untuk beradaptasi.

Adaptasi merupakan kemampuan individu agar dapat melakukan penyesuaian diri pada suatu tempat atau lingkungan yang dipandang sebagai suatu hal yang baru. Adaptasi dapat juga diartikan sebagai proses penyesuaian diri dalam mengubah diri sesuai dengan keadaan lingkungan, tetapi dapat juga mengubah lingkungan sesuai dengan keadaan atau keinginan diri (Gerungan, 1996). Kemampuan setiap orang untuk beradaptasi pun berbeda-beda. Terdapat banyak faktor yang mempengaruhi kecepatan dan cara seseorang beradaptasi seperti, kepribadian, usia, pengalaman, proses belajar, kondisi fisik, dan lingkungan (Ali \& Asrori, 2011). Oleh karena perbedaan kemampuan beradaptasi pada setiap individu tersebut maka proses adaptasi akan berujung kesuksesan beradaptasi atau kegagalan beradaptasi. Kesuksesan beradaptasi akan melahirkan daya lenting atau resiliensi pada diri seseorang. Sedangkan kegagalan beradaptasi akan berdampak pada penurunan kondisi kesehatan mental

\section{Penutup}

Stress adalah sesuatu yang tidak dapat dihindari ketika berada pada kondisi penuh tekanan seperti di masa pandemi COVID-19. Salah kunci penting mengelola stress adalah pada penyeleksian informasi yang diterima dalam kurun waktu tertentu. Informasi tersebut hendaklah bersal dari sumber terpercaya dan memiliki kredibilitas di bidangnya. Jika mulai merasa memiliki gejala gangguan mental ringan, langkah awal adalah minta pertolongan pada lingkungan terdekat yang dipercaya, bisa pasangan, orangtua, kakak, atau sahabat. Jika hal tersebut kurang berhasil maka meminta bantuan pihak yang kompeten seperti ahli kejiwaan juga merupakan jalan keluar yang baik. Klinik kesehatan mental lainnya menawarkan dukungan daring (online) atau kunjungan ke rumah melalui konseling dan psikoterapi . 


\section{Daftar Pustaka}

Aufar, A.F.\& Raharjo, S.T. 2021. KEGIATAN RELAKSASI SEBAGAI COPING STRESS DI MASA PANDEMI COVID-19. JURNAL KOLABORASI RESOLUSI KONFLIK. 2 (2), hal. 157-163.

Cullen, W., Gulati, G., Kelly, G.D. 2020. Mental health in the COVID-19 pandemic. International Journal of Medicine. 113(5):311-312

Handayani, R.T. dkk. 2020. FAKTOR PENYEBAB STRES PADA TENAGA KESEHATAN DAN MASYARAKAT SAAT PANDEMI COVID-19. Jurnal Keperawatan Jiwa. 8 (3), hal. $353-358$

Rahmawati, T. 2021. PENINGKATAN PENGETAHUAN DAN MANAJEMEN STRESS DI MASA PANDEMI COVID-19 BAGI MASYARAKAT. Jurnal Masyarakat Mandiri. 5 (1), hal. $125-133$

Rifani, D.A. 2021. Ketidakstabilan Emosi dan Mood Masyarakat Dimasa Pandemi Covid-19. Jurnal Manajemen Bisnis. 18 (1), hal. 22-34

Shabuur, M.I \& Mangundjaya, W.L. 2020. Pengelolaan stres dan peningkatan produktivitas kerja selama work from home pada masa pandemi covid-19. Jurnal Psikologi Udayana. 7(2), hal. 93-10

Vibriyanti, D. 2020. KESEHATAN MENTAL MASYARAKAT: MENGELOLA KECEMASAN DI TENGAH PANDEMI COVID-19. JURNAL KEPENDUDUKAN INDONESIA, hal.67-94

Vinkers, C.H. et al . 2020. Stress resilience during the coronavirus pandemic. European Neuropsychopharmacology. 35, $12-16 \mathrm{~s}$ 